\title{
Overcoming Indoor Air Pollutants by Using Wall Gardens - Carbon Dioxide Study Case
}

\author{
Raghda Ramadan Abd- elaziz ${ }^{1}$, T.M.El-keiy ${ }^{1}$, E.A. Shalaby ${ }^{2}$ and A.M. Shehata ${ }^{1}$ \\ ${ }^{1}$ Faculty Agriculture (ELshatby), Alex.Univ. \\ ${ }^{2}$ Inst Grad Studies \& Res. Alex. Univ.
}

\begin{abstract}
This study reviews the effect of indoor plants on overcoming indoor air pollutants like $\mathrm{CO}_{2}$ when using wall garden units planted with Syngonium and Pothus in different arrangements as an indoor decorative unit which can be used in closed work places. This study was taken at Bibliotheca Alexandrina back offices where employees are subjected to all of the indoor workspace conditions during their work hours. Eight identical offices were chosen where six wall gardens were installed and the pollutants were monitored for 13 weeks, and a questionnaire was given to the employees. It was found that introducing wall gardens to indoor closed workspace not only reduced some of the pollutants values but also had positive effects on the employees. Another prospective for this study was to spread the idea of the importance of green plants in our lives in a simple way that can reach those who got no back ground about plants, also it was a target to create the most appealing and on budget methods for setting indoor gardens as people pay more attention to indoor construction and decoration at the lowest cost and most appealing shapes, in order to encourage people who find themselves locked indoor in their homes and at workspace for more than six hours every day and accordingly exposed to all the indoor pollutants due to the unavoidable synthetic materials and furnishings products used in these buildings that are sources of air pollutants to install their own wall gardens by themselves or by specialized companies. Pothus and Syngonium were planted in wall gardens and the readings of $\mathrm{CO} 2$ were taken on daily bases using Fluke 975 AirMeter $^{\mathrm{TM}}$ to monitor Carbon dioxide, the device is owned by the Engineering Sector of Bibliotheca Alexandrina and calibrated on 2016.
\end{abstract}

Key words: Indoor air pollution- Air quality- Bio filtration - wall gardens- green walls.

\section{INTRODUCTION}

Indoor air pollution is ranked as one of the world's greatest public health risks as it often contain five to seven times the contaminant concentrations of outdoor city air and the harmful effects of these mixtures have been recognized as components of 'sick building syndrome' or 'building-related' with symptoms of headache, dizziness, nausea, sore eyes and throat, or loss of concentration. Biophilic workspaces and interaction with plants may change human attitudes, behaviors, improve mood, productivity and the overall wellbeing as generally potted plants add a certain aesthetic value to homes and offices by bringing a touch of nature to the lifeless indoor spaces specially work places, as modern lifestyles can result in people spending more than $90 \%$ of each day indoor. Accordingly indoor air quality has a strong effect on personal health as well as on comfort and productivity, and as for the limited spaces, it was found that Green walls and green roofs are considered promising approach for greening cities where green areas are scarce and ground spaces as green areas are limited. Previous studies have shown that applying greenery in urban areas has numerous environmental, economic and social benefits (K. Shiah, J.W. Kim, S. Oldridge, (2011). Plants clean and freshen the air by absorbing dust, consuming carbon dioxide and releasing oxygen, although maintaining the balance of the complete ecological cycle involves treating and recycling sewage, toxic chemicals, and other industrial water and air pollutants. Only indoor air is addressed here, especially as modern life is urging man to spend less time in nature and rushing man to modernize his indoor space using synthetic materials and reducing the green areas in cities . It is obvious now that this indoor heaven is so fake and it only pushed man into isolating himself more from the nature and intensify the exposure to indoor air pollutants arising from all the synthetic materials that used to build his own indoor world, and by constructing more buildings that are not connected to nature and not linked with green areas and then being obligated to lock himself inside those buildings for more than $90 \%$ of his time each day at work, schools, shopping malls and homes which are all not healthy, leading to destroy his own health on the long run by manufacturing chemicals which are not environmentally friendly. these all have leaded to serious arising indoor air pollution problems for his health, productivity and wellbeing. Accordingly, the widespread concern about buildings occupants have been an essential element in maintaining good indoor air quality (IAQ) and considered one of the top priority for designers, building managers and occupants as well. The challenge is greater today because there are many new synthetic materials, furnishings, products and processes are being used 
in these buildings that are considered sources of air contamination. The attributes of good indoor air quality include control of indoor air pollution, the introduction and distribution of adequate ventilation, and the maintenance of acceptable temperature and relative humidity. During the late 1970s, when the energy crisis was being felt at both heating and cooling costs, buildings were being designed to maximize energy efficiency to help alleviate spiraling energy costs but upon the occupation of these buildings, the workers began to complain of various health problems such as itchy eyes, skin rashes, drowsiness, respiratory and sinus congestion, headaches, and other allergy-related symptoms. It was determined that the airtight sealing of buildings contributed significantly to the workers' health problems. Similarly, synthetic building materials, which are known to emit or "off-gas" various organic compounds, have been linked to numerous health complaints and may adversely affect inhabitants of these buildings. The office equipment and furnishings placed in these buildings are also a contributing factor due to the types of materials used in their manufacture and design. Also when a large number of persons occupy a certain closed place the pollution due to the respiration process become dangerous and may lead to health problems. The problems of indoor air pollution have been studied and documented over the past ten years proving that sick building syndrome's symptoms are reduced in naturally well ventilated buildings but the highest levels of symptoms are found in mechanically ventilated buildings. In this study, it was a prospective to encourage people from different age categories to adopt simple ideas with low costs like the idea of the wall garden as it gathers maximum number of plants in limited area of space as it could be used as a simple low cost unit filled with natural life system suitable for closed places which are poorly ventilated as a possible means of reducing indoor air pollutants and in order to allow man to move a piece of living nature into his closed environment at which he is spending most of his days, it is as if man could be capable of taking along nature's life support system inside his closed spaces which are mostly too small to let us put a potted plant of suitable size and take care of it. Also it is shown the ability of green plants to reduce the high concentrations of indoor air pollutants such as carbon dioxide and also enhance better mood and better awareness of the importance of indoor green plants were shown among the study case which is an ever reminder for the man of his dependence on plants for his continued existence and well-being on Mother Earth.

\section{MATERIALS AND METHODS}

This study had taken place at the back offices of Bibliotheca Alexandrina where eightidentical offices were selected which all got the same conditions (type of ventilation, HVAC controls, light system, humidity, number of occupants who spend eight hours, area, fumiture and type of work).. two offices were control unit, six wall gardens were installed at the other six offices, two of them were planted by Pothus only (figure 3 pothus only wall garden installed), two of them were planted by Syngonium only and two of them were planted by half Syngonium and half Pothus. All the tested plants were obtained from nurseries in the local area and planted in the pockets of the wall garden in peat moss as growing media which was free of pathogens. Readings of air pollutants were taken daily for successive 10 days prior to installing the wall gardens in the eight rooms to estimate the average values of air pollutants inside the rooms without any plants(see Table 1), then the samples were drawn daily for thirteen weeks to monitor the rates of pollutants inside the rooms. As an additional prospective, a questionnaire was given to the employees who are working inside the rooms at which the wall gardens had been installed in order to inspect their overall impressions about having green plants in their work space.

The wall garden unit dimensions is $81 \mathrm{cms}$ X 97 cms(see Figure 1 the wall garden unit (empty), Figure 2 wall garden unit in process of planting\& Figure 3 installed Pothus only wall garden), it contains 21 pockets each pocket is $12 \mathrm{cms}$ X 25 $\mathrm{cms}$, the body of the wall garden is made of felt wool fabric of $3 \mathrm{~mm}$ thickness in grey color, pockets were folded and stapled on a Polycarbonatedplastic board in order to protect the walls of the buildings from being affected by the humidity. The last row of pockets were secured by wrapping it from the outside by recycled polyethylene to prevent any leakage of the irrigation water. The unit was hanged by enforced metal wires. The irrigation was done every other day manually using a plastic watering pot, by applying the slightest amount of water in each pocket, the growing media was sprayed gingerly in order to keep the medium moist yet avoiding complete dryness and any rotting of the plants root system inside the pockets

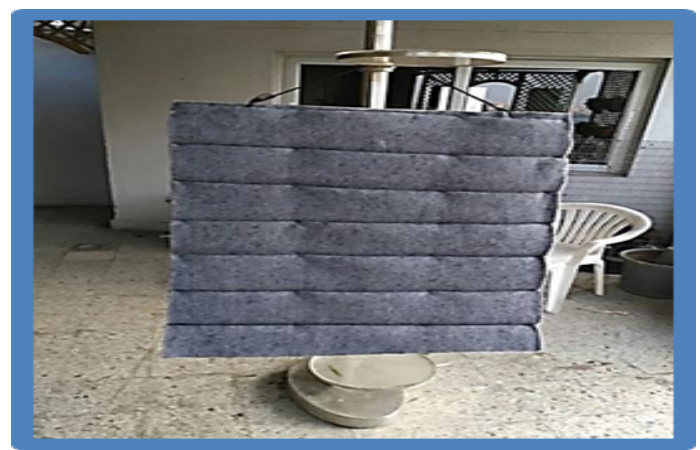

Figure 1: the wall garden unit (empty) 


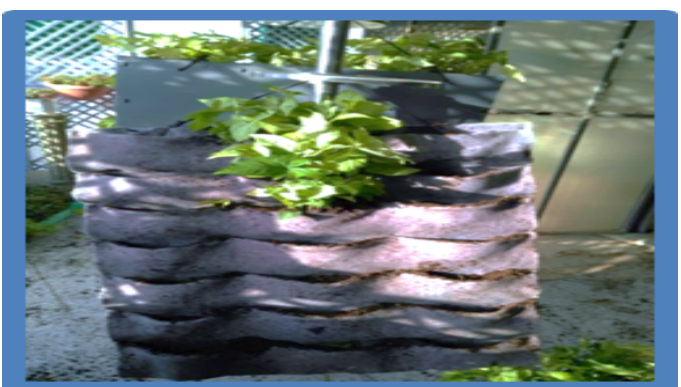

Figure 2: wall garden unit in process of planting

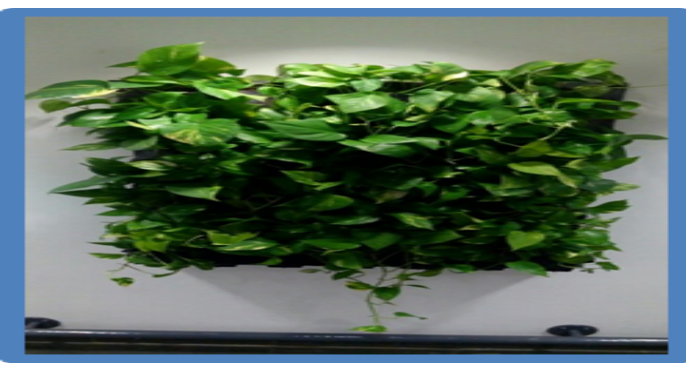

Figure 3: pothus only wall garden installed

Readings were taken from the eight empty chambers daily for ten days before starting the experiment using Fluke 975 AirMeter $^{\mathrm{TM}}$ to monitor Carbon dioxide which is owned by the Engineering Sector of Bibliotheca Alexandrina which had assisted this study by allowing us to monitor the readings using their own devices which were calibrated at 2016 (see Figure 4).

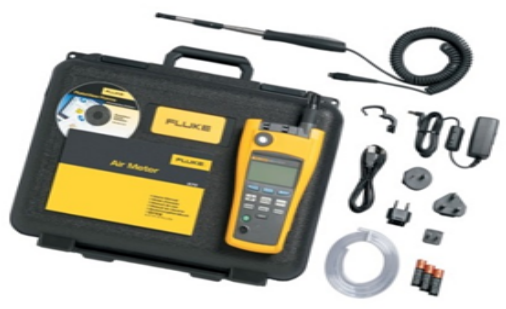

Figure 4: Fluke 975V AirMeter ${ }^{\mathrm{TM}}$

\section{RESULTS AND DISCUSSION}

Pothus only wall gardens succeeded in reducing $\mathrm{CO} 2$ by about $51 \%$, and Syngonium only wall gardens succeeded in reducing $\mathrm{CO} 2$ by about $41 \%$, while Pothus + Syngonium wall gardens succeeded in reducing CO2 by about $42 \%$.

Table 1: the average values of $\operatorname{co} 2$ for 10 succsive days before installing wall gardens

\begin{tabular}{ll}
\hline Room & CO2 \\
\hline 1 (Pothus only wall garden) & $859 \mathrm{ppm}$ \\
\hline 2 (Pothus only wall garden) & $770 \mathrm{ppm}$ \\
\hline 3 (Syngonium only wall garden) & $788 \mathrm{ppm}$ \\
\hline 4 (Syngonium only wall garden) & $757 \mathrm{ppm}$ \\
\hline 5 (Pothus + Syngonium wall & $776 \mathrm{ppm}$ \\
\hline 6 (Pothus + Syngonium wall & $803 \mathrm{ppm}$ \\
\hline 7 (control room - no plants) & $792 \mathrm{ppm}$ \\
\hline 8 (control room - no plants) & $702 \mathrm{ppm}$ \\
\hline
\end{tabular}

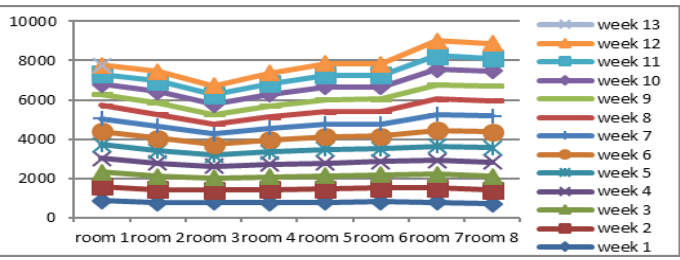

Graph 1: Relationship between the values of CO2 over the 13 weeks' time interval of the experiment

The following questionnaire was given to 40 employees, 28 of them were the residents of the offices at which the wall gardens were installed and the experiment was taken. The other twelve employees are located and working near the corridors at which another unit of wall garden was installed which made them average users of this area so they were visually affected. All employees spend average of 8 hours, they are between $21-60$ years old with works types:

Table 2: The average values (in ppm) of weekly readings of $\mathrm{CO}_{2}$ for the 13 weeks from the 8 rooms

\begin{tabular}{cccccccccccccc}
\hline & $\mathbf{W}$ & $\mathbf{W}$ & $\mathbf{W}$ & $\mathbf{W}$ & $\mathbf{W}$ & $\mathbf{W}$ & $\mathbf{W}$ & $\mathbf{W}$ & $\mathbf{W}$ & $\mathbf{W}$ & $\mathbf{W}$ & $\mathbf{W}$ & $\mathbf{W}$ \\
& $\mathbf{1}$ & $\mathbf{2}$ & $\mathbf{3}$ & $\mathbf{4}$ & $\mathbf{5}$ & $\mathbf{6}$ & $\mathbf{7}$ & $\mathbf{8}$ & $\mathbf{9}$ & $\mathbf{1 0}$ & $\mathbf{1 1}$ & $\mathbf{1 2}$ & $\mathbf{1 3}$ \\
\hline $\mathbf{R} 1$ & 850 & 741 & 725 & 712 & 688 & 675 & 661 & 654 & 587 & 510 & 500 & 472 & 379 \\
& $\mathrm{ppm}$ & $\mathrm{ppm}$ & $\mathrm{ppm}$ & $\mathrm{ppm}$ & $\mathrm{ppm}$ & $\mathrm{ppm}$ & $\mathrm{ppm}$ & $\mathrm{ppm}$ & $\mathrm{ppm}$ & $\mathrm{ppm}$ & $\mathrm{ppm}$ & $\mathrm{ppm}$ & $\mathrm{ppm}$ \\
\hline $\mathbf{R 2}$ & 760 & 680 & 672 & 655 & 641 & 629 & 618 & 610 & 595 & 560 & 548 & 475 & 398 \\
& $\mathrm{ppm}$ & $\mathrm{ppm}$ & $\mathrm{ppm}$ & $\mathrm{ppm}$ & $\mathrm{ppm}$ & $\mathrm{ppm}$ & $\mathrm{ppm}$ & $\mathrm{ppm}$ & $\mathrm{ppm}$ & $\mathrm{ppm}$ & $\mathrm{ppm}$ & $\mathrm{ppm}$ & $\mathrm{ppm}$ \\
\hline $\mathbf{R 3}$ & 784 & 630 & 612 & 580 & 571 & 555 & 531 & 504 & 500 & 501 & 488 & 473 & 468 \\
& $\mathrm{ppm}$ & $\mathrm{ppm}$ & $\mathrm{ppm}$ & $\mathrm{ppm}$ & $\mathrm{ppm}$ & $\mathrm{ppm}$ & $\mathrm{ppm}$ & $\mathrm{ppm}$ & $\mathrm{ppm}$ & $\mathrm{ppm}$ & $\mathrm{ppm}$ & $\mathrm{ppm}$ & $\mathrm{ppm}$ \\
\hline $\mathbf{R} 4$ & 752 & 677 & 650 & 633 & 629 & 611 & 599 & 580 & 570 & 570 & 553 & 540 & 431 \\
& $\mathrm{ppm}$ & $\mathrm{ppm}$ & $\mathrm{ppm}$ & $\mathrm{ppm}$ & $\mathrm{ppm}$ & $\mathrm{ppm}$ & $\mathrm{ppm}$ & $\mathrm{ppm}$ & $\mathrm{ppm}$ & $\mathrm{ppm}$ & $\mathrm{ppm}$ & $\mathrm{ppm}$ & $\mathrm{ppm}$ \\
\hline R5 & 769 & 680 & 670 & 668 & 678 & 652 & 645 & 625 & 630 & 633 & 615 & 590 & 415 \\
& $\mathrm{ppm}$ & $\mathrm{ppm}$ & $\mathrm{ppm}$ & $\mathrm{ppm}$ & $\mathrm{ppm}$ & $\mathrm{ppm}$ & $\mathrm{ppm}$ & $\mathrm{ppm}$ & $\mathrm{ppm}$ & $\mathrm{ppm}$ & $\mathrm{ppm}$ & $\mathrm{ppm}$ & $\mathrm{ppm}$ \\
\hline R6 & 806 & 690 & 681 & 668 & 655 & 644 & 639 & 630 & 618 & 619 & 612 & 550 & 486 \\
& $\mathrm{ppm}$ & $\mathrm{ppm}$ & $\mathrm{ppm}$ & $\mathrm{ppm}$ & $\mathrm{ppm}$ & $\mathrm{ppm}$ & $\mathrm{ppm}$ & $\mathrm{ppm}$ & $\mathrm{ppm}$ & $\mathrm{ppm}$ & $\mathrm{ppm}$ & $\mathrm{ppm}$ & $\mathrm{ppm}$ \\
\hline R7 & 792 & 705 & 700 & 710 & 730 & 802 & 823 & 790 & 721 & 784 & 695 & 758 & 821 \\
& $\mathrm{ppm}$ & $\mathrm{ppm}$ & $\mathrm{ppm}$ & $\mathrm{ppm}$ & $\mathrm{ppm}$ & $\mathrm{ppm}$ & $\mathrm{ppm}$ & $\mathrm{ppm}$ & $\mathrm{ppm}$ & $\mathrm{ppm}$ & $\mathrm{ppm}$ & $\mathrm{ppm}$ & $\mathrm{ppm}$ \\
\hline R8 & 700 & 700 & 705 & 715 & 738 & 811 & 800 & 802 & 752 & 750 & 650 & 760 & 803 \\
& $\mathrm{ppm}$ & $\mathrm{ppm}$ & $\mathrm{ppm}$ & $\mathrm{ppm}$ & $\mathrm{ppm}$ & $\mathrm{ppm}$ & $\mathrm{ppm}$ & $\mathrm{ppm}$ & $\mathrm{ppm}$ & $\mathrm{ppm}$ & $\mathrm{ppm}$ & $\mathrm{ppm}$ & $\mathrm{ppm}$ \\
\hline
\end{tabular}




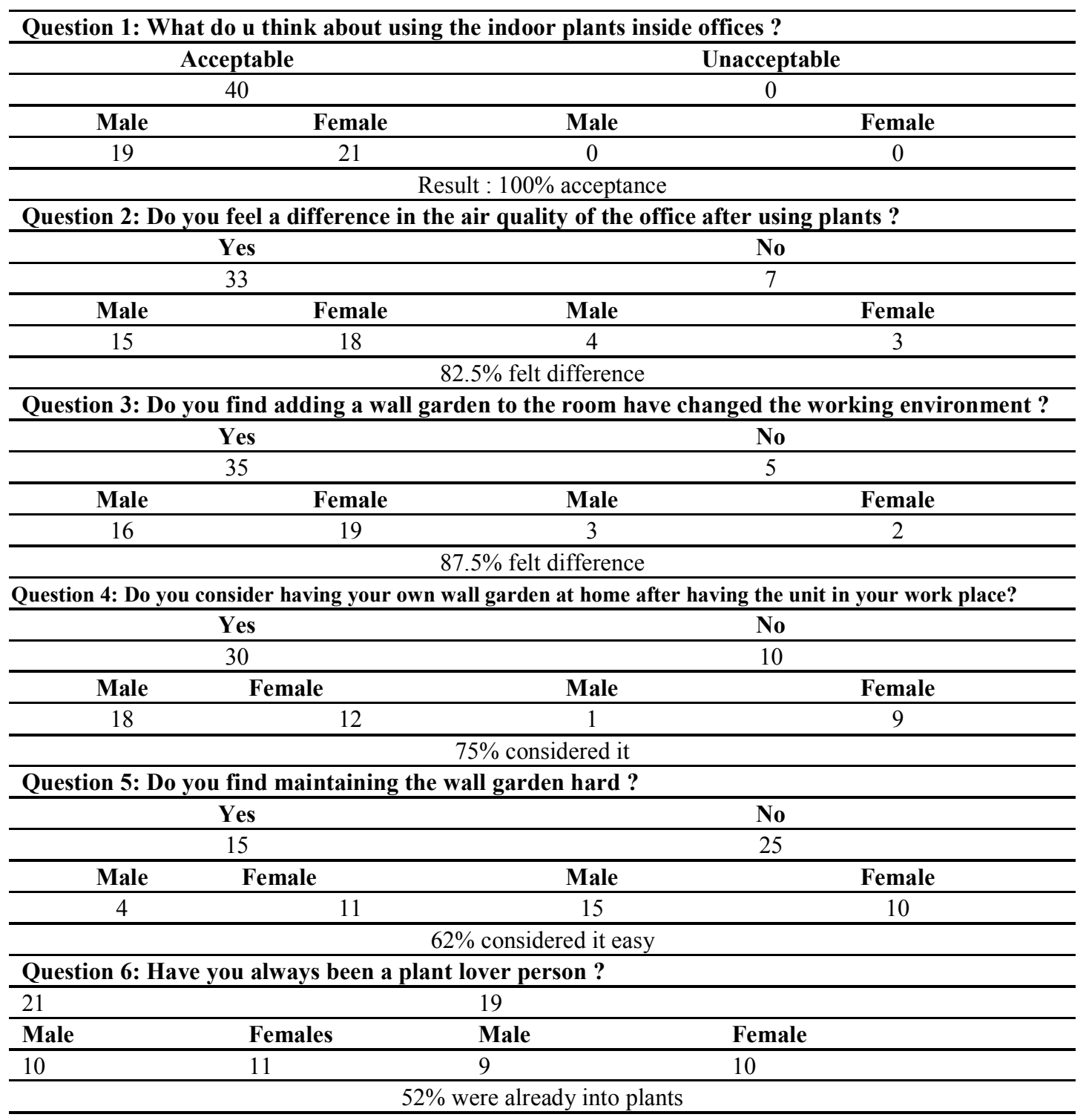

Question 7: Do you feel much more interested in plants after having wall garden in your workplace?

\begin{tabular}{clcc}
\hline & 35 & & 5 \\
\hline Mal & Female & Male & Female \\
\hline 17 & 18 & 2 & 3 \\
\hline
\end{tabular}

$87.5 \%$ stated that this experiment had encouraged them more to be more interested about plants while only $5 \%$ showed no interest

Question 8: Have you been interested in checking the new growing leaves and the color changing of the plants in the wall garden unit?

\begin{tabular}{|c|c|c|c|}
\hline \multicolumn{2}{|r|}{30} & \multicolumn{2}{|r|}{10} \\
\hline Male & Female & Male & Female \\
\hline 12 & 18 & 7 & 3 \\
\hline \multicolumn{4}{|c|}{$75 \%$ were interested in checking the plants } \\
\hline \multicolumn{4}{|c|}{ Question 9: Have your guests commented on the wall garden in your workplace positively? } \\
\hline 24 & & 16 & \\
\hline Male & Female & Male & Female \\
\hline 12 & 12 & 7 & 9 \\
\hline
\end{tabular}




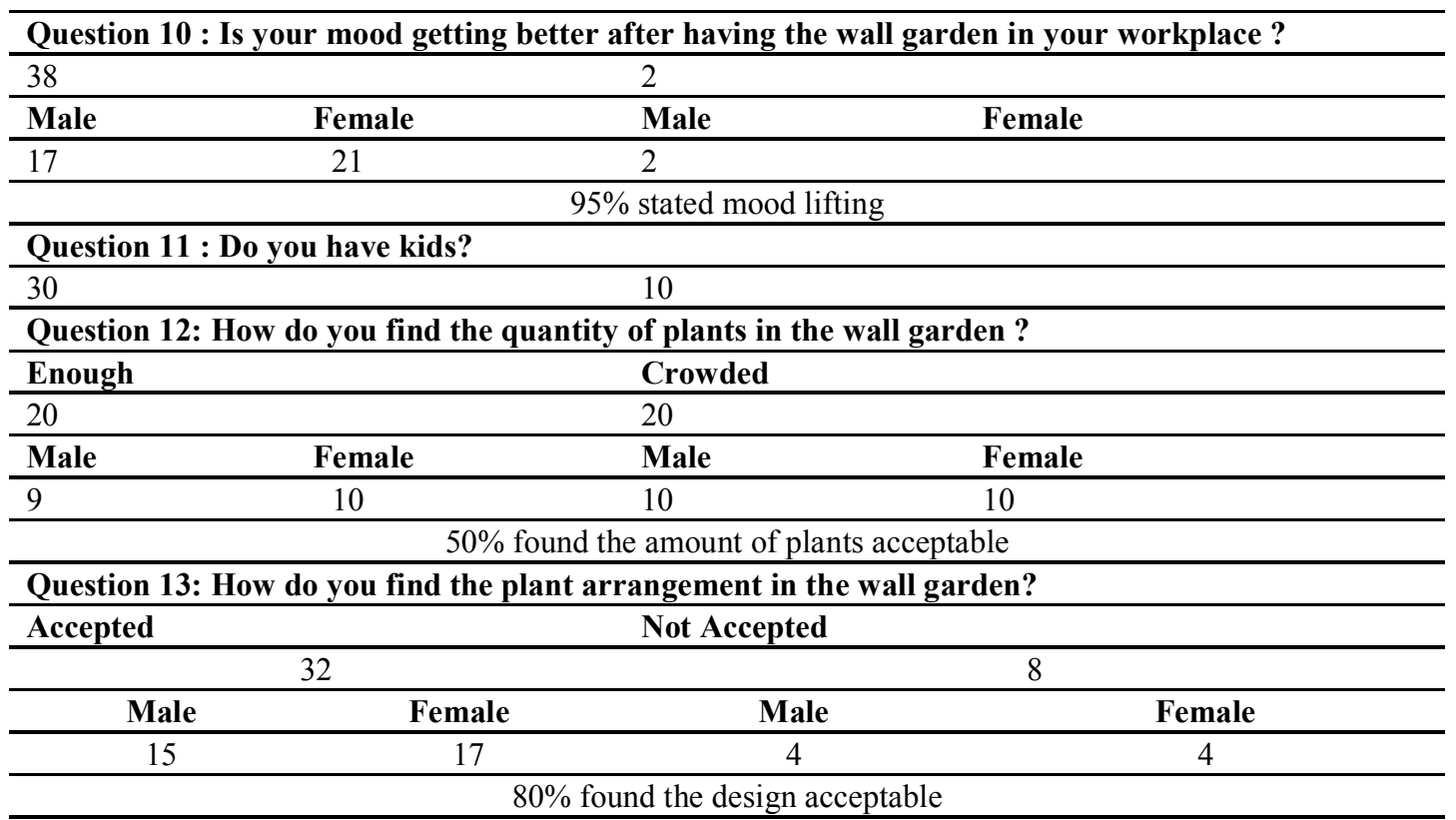

Question 14: do you find the plants used compatible and in coordination with the colors of the surroundings?

\begin{tabular}{|c|c|c|c|}
\hline \multicolumn{2}{|c|}{ Compatible } & \multicolumn{2}{|c|}{ Incompatible } \\
\hline \multicolumn{2}{|r|}{37} & \multicolumn{2}{|c|}{3} \\
\hline Male & Female & Male & Female \\
\hline 17 & 20 & 2 & 1 \\
\hline \multicolumn{4}{|c|}{$92.5 \%$ found the wall gardens compatible } \\
\hline \multicolumn{4}{|c|}{ Question 15 : How do you find the idea of the research? } \\
\hline \multicolumn{2}{|c|}{ Good } & \multicolumn{2}{|c|}{ Bad } \\
\hline \multicolumn{2}{|r|}{37} & \multicolumn{2}{|c|}{3} \\
\hline Males & Female & Males & Female \\
\hline 18 & 19 & 1 & 2 \\
\hline
\end{tabular}

Question 16: what is your favorite plant or flower?

Pothus - Tulip - Roses - Areca - Cycas - Syngomium

Question 17: what is your favorite plant from the ones used in the wall gardens?

\begin{tabular}{|c|c|c|c|c|c|c|}
\hline Pothus & & & Syngoni & & & \\
\hline 35 & & & 5 & & & \\
\hline Male & Female & & Male & & Female & \\
\hline 18 & 17 & & 1 & & 4 & \\
\hline & & $87.5 \%$ & ere found & e Pothus & & \\
\hline & & & Age cate & & & \\
\hline $21-30$ & & & & & & \\
\hline 4 & & & & & & \\
\hline Female & Male & Female & Male & Female & Male & Female \\
\hline 2 & 8 & 10 & 5 & 5 & 6 & 2 \\
\hline
\end{tabular}

The employees were also given the opportunity to add any other comments at the end of the second survey. As is often the case with this type of surveys. Several comments were received regarding the plants and the idea of the wall gardens . although in previous studies by (Smithet al.2011) it was mentioned that they got some comments about the increase in flies within the office for which the plants were blamed in most instances and it was stated by the researchers that the plants were not the cause as the plants in question were hydroculture varieties with which the growing medium would have been an unsuitable habitat for the flies so more likely the source was fruit or coffee cups left on workstations, However, the perception that the plants were the cause of the flies may have 
adversely affected some people's perceptions of the plants themselves, several positive comments about the plants were also received, suggesting that the work area could be more pleasant with more plants and that they could be used for cooling and insulation. This research evaluated the indoor air quality of a number of offices inside Bibliotheca Alexandrina main building. The control over the conditions as fixed factors, namely relative humidity, temperature, and light intensity and duration confirmed that the results are only related to other factors and the justified values of the fixed factors mentioned worked well with the growth and development of the selected types of plants. This study's main aims were to indicate that if using Pothus and Syngonium in different combinations as indoor plants in the form of wall gardens at which we can plant many plants in a limited space has the ability to reduce some of the indoor pollutants and another aim was an attempt to understand the effect of having indoor plants on the employees who happened to have no agricultural background, another aim was to know if having indoor plants can push people to be more interested in plants in order to spread more awareness of the importance of having a living entity around them as long as they are tending to be separated from nature as a reason of working for long hours indoors. also it was important to know if installing a simple prototype wall garden inside offices of limited spaces could be a practical idea without blocking the flow of motion or spoling the furniture. Pothus only wall gardens succeeded in reducing $\mathrm{CO} 2$ by about $51 \%$, and Syngonium only wall gardens succeeded in reducing $\mathrm{CO} 2$ by about $40 \%$, while Pothus + Syngonium wall gardens succeeded in reducing $\mathrm{CO} 2$ by about $42 \%$. Also here are some points that should be considered in controlling indoor pollution according to previous studies:

1. Biophilic design should be considered vital as inclusion of natural elements in enclosed environments got positive impacts.

Having plant element as in wall gardens (Biophilic) is considered as a design features that reconnect people with nature It increases the overall satisfaction and happiness of people's lives. it was supported by a previous by Hami et al. ( 2018) study that people prefer a mall environment which is coherent and legible pointing out to the important role of green and natural elements in people's preferences to interior spaces as in shopping malls. Many researchers by Coleman, (2006), Lohr, et al.. (2000) \& Kaplan, R., \& Kaplan, S. (1989) emphasized the natural elements, believed to provide psychological benefits to people. In another studies by Todorova et al.(2004) \& Manaker(1996) had similarly found that indoor plants were proven to create healthy atmosphere naturally by removing harmful pollutants in the indoor air .

\section{Productivity}

According to a previous study by Roelofsen, (2002), an increase in performance may be expressed as a directly quantifiable reduction of absenteeism where that previous study's data shows that in the experimental area, where the plants were installed, there was a significant reduction in short term sickness absence level suggesting that in their study that the presence of plants helped reduce sickness absence and supported by the fact that in the control area with no plants, there was an increase in sickness absence. In another study by Smith et al. (2011), significant differences were found between the experimental and control groups for the work environment contributing to pressure, health concerns, morale and preference for plants. Sickness absence reduced substantially in the area with plants and increased slightly in the control area.

3. Plants in buildings can increase social skills

According to Almusaed(2011), it was proved that having plants in buildings can increase social skills by contributing to more supportive patterns of interrelations among its

\section{There should be standards for work places in} order to be licensed

a) A Clean-Healthy indoor work space standard should be designed to ensure a certain level of indoor air quality and ventilation.

b) Continued funded researches are required to establish a risk index for health and comfort effects for indoor pollutants in non-industrial buildings.

c) There should be a governmental institute specialized in auditing the workspaces and reporting their air quality statement as a Standard Evaluation Report and submit it to the government office in order to ensure that the people working in these buildings are having a suitable environment to save their health from further risks on the long run which in turn save lots of money which the government bear yearly on the health insurances. As encouragement to push more organizations to go green and getting involved in caring about indoor air quality standards, government could reduce the Taxes for the organization which operates the buildings which are going green and according to the air quality index standards applied and this could be judged and controlled by the regular inspection visits audits by the government representor to check such buildings.

d)Each building should be having quality control specialists who review the work places internally in order to ensure the House Building Standard are correctly applied .

e) Newly built work spaces blocks should apply the minimum standard items, to be recognized and 
certified as a Clean-Healthy House which accordingly should give it a good value in the real estate market.

\section{Jobs and Investment Opportunities}

a) It can be assumed that as more cities invest in green infrastructure, then more opportunities will be created for trained workers in green infrastructure employment, as well as in the associated supply chain, including nurseries, environmental restoration, management and conservation. Demand for green-collar labor is therefore predicted to increase, and methods are being developed to determine the impact of green training programs on local communities.

b)Infrastructure can provide a competitive advantage at local scales through inward investment, visitor spending, new job creation, and health Sustainability and environment improvement, it has been demonstrated that a majority of the ecological restoration projects provided net benefits, not only being profitable but also creating high-yielding as mentioned by McCalley, James, et al. (2010). As it is the case in Europe, especially Germany, green market is growing rapidly $20-30 \%$ a year as mentioned by Peck, S., et al. (1999). Therefore it is not hard to imagine that vertical garden will create a new job opportunities for the new cities.

c) Buildings with interior green planting are view as more expensive-looking, more welcoming to its residents as mentioned by Shiah, K., \& Kim, J. (2011). Strong associations between the moisture in growth media, vegetation coverage and cooling effect demonstrate the importance of maintaining a healthy plant cover and a hospitable substrate. What really happens at the wall of buildings is that vertical garden can actually protect building material from UV radiation, driving rain, ice accretion, tear cause by moisture, and temperature difference. For maintenance, little is need once the plants have established. Also that study had showed that having a green plant can increase the value of property by $6-15 \%$.

\section{Indoor plants and stress}

Employees in the rooms at which the green walls were installed commented that they are feeling less stressed and were able to concentrate much better in their indoor tasks leading to better productivity - Although there is no solid data that prove that it has a strong impact on the performance, productivity and overall reduction of the Sick Building Syndrome. In fact, there is a field of horticulture therapy that promotes plant-human relationships to induce relaxation and to reduce stress, fear, anger, and blood pressure and muscle tension as per Brown, K. \& Jameton, (2000). In the study by Fjeld,(1995) it was showed that an inclusion of green plants in offices and work environment has resulted in $5-15 \%$ reduction in absenteeism. Another study by Lohr, et al. (1996) it was demonstrated that plants inside classrooms reduce the stress level and $12 \%$ increase in productivity of students., also in an experiment indicates that the stress-reducing effects of nature interventions in the built healthcare environment are the result of a higher level of perceived attractiveness of such environments as mentioned by Dijkstra et al.(2011).

\section{Plants is a good solution for biofiltration while staying on budget}

As recommended at the study by Vazquez, K et al.(2014) the importance of introducing efficient and cost effective methods to decrease indoor pollutants was studied. Through many studies that were reviewed and done by former researchers, it was obvious that indoor plants are capable to serve as bio-filtration and It is interesting to purify the indoor air using a minimum or without energy, which would be beneficial to humans as mentioned by Wang, (2011), Shamsuri, et al.(2015), Rajkhowa, Bhargav R, (2016), Wolverton, et al. (1989), Zhou, J. et al. (2011) Despite growing evidence for the cognitive, emotional, and physical health benefits of interacting with nature, constructed indoor workspaces devoid of nature remain all-toocommon. In fact, some workplaces are even removing their plants in attempts to save money as mentioned by Mangone, Giancarlo, et al, 2017)

\section{Beautification with respect to the environment} and the wellbeing of employees should be considered more

Rooms with wall gardens were rated more attractive than the one without the wall garden. Studies showed that having a green plant can increase the value of property by $6-15 \%$. Peck, S., et al. (1999). New solutions must focus not only in the application in new buildings but also in the rehabilitation of existing buildings, introducing greening in historical areas, Systems adaptability is still a field of development as mentioned by Virtudes. A, Manso. M,(2012). Increased green amenity space means that the bad designs can be disguised and become unnoticed as mentioned in a study by Peck, et al.(1999). According to recent studies It can be safely concluded that it should be of great interest to include plants as a work environment asset, since only small investments are necessary in order to establish a "green" indoor environment. In addition - and probably just as important - the personal well-being and the quality of the everyday working situation may be increased for the employees as many studies had stated that productivity is positively correlated with satisfaction with exposure to plants in the office environment as mentioned in a study by Groenewegen \& Peter P., (2012). In addition, vertical gardens have demonstrated that restorative effect of natural 
scenery holds the viewer's attention, diverts their awareness from themselves and from worrisome thoughts and elicits a meditation-like state as mentioned in a study by Peck, et al.(1999).

9. Awareness about the importance of green plants

\section{New type of tourism and fine arts}

Patrick Blanc who is a French botanist and designer who invented the concept of the vertical garden and has been on a quest to green walls across the planet with his plant-based creations for the last 25 years.inaugurated a new vertical garden blanketing 2,700 square feet of an 82-foot-tall wall with 236 different kinds of plants. The plant wall is designed in a verdant wave pattern on a formerly drab southwest-facing Parisian street corner at 83 de la Rue d' Aboukir in the 2nd arrondissement. He calls it a "hymn to biodiversity"

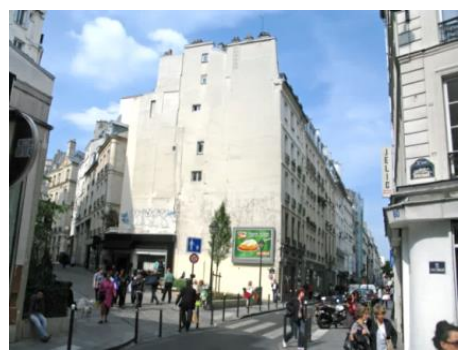

Figure 5: Patrick's Blanc's blank canvas on rue d'Aboukir (Blanc, 2015).

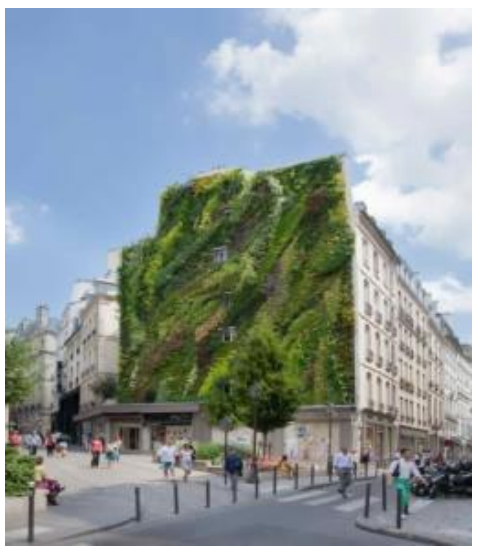

Figure 6: L'Oasis d'Aboukir, a new vertical garden on the side of a residential building in Paris (Blanc, 2015)

11. Awareness about the types of indoor furnishing materials should be considered to give the consumer the full will to choose what he's breathing in.

More specialized studies are needed in this field to allow more options for the consumers with good prices. Another prospective of the same idea of restricting the materials and products which have negative effects on the human and environment is at least helping the consumer to choose what he is purchasing in other words manufacturers should be obligated to illustrate the components of their products on each product in order to give the option for the consumer to choose, according to his budget and any other factor included in his choice. The more consumers request such information, the sooner it will become widely available.

12. Space planning and placing the indoor plants in the workspace should be with respect to the Ventilation systems applied

The use and placement of furniture, equipment and indoor plants may affect the delivery of air to an occupied space. indoor plants should never be placed under $\mathrm{AC}$ vents as that was found to harm the plant by injuring the leaves as it causes wilting.

\section{Controlling indoor air quality}

This needs integrating 5 main concepts which are managing the sources of pollutants either by removing them from the building or isolating them from people through physical barriers as plants as for wall gardens or simple potted plants, second by limiting the timing of employees who work indoors being inside offices by obligated them to go out for breaks in open areas accompanied by the workplace in order to give them some recovery from the consistent exposure with long run dangers, Third is by using diluted forms of pollutants sources as for with less amounts of components which cause problems (like paints, fabrics ..etc) or may be replace them with environment friendly options, fourth is upgrading the buildings ventilation in order to guarantee enough fresh air to overcome the trapped polluted air inside the offices, fifth is using means of air filtration to clean the air of pollutants.

14. Creating an indoor air profile of the building.

IAQ profile is a description of the features of the building structure, function, and occupancy that impact indoor air quality. When you have completed the IAQ profile, you should have an understanding of the current status of air quality in the building and baseline information on the factors that have a potential for causing problems in the future (epa, 2014)

\section{Barriers that prevent widely applying}

It was mentioned by Peck, et al.(1999) even with all the benefits of vertical garden, there are barriers that prevent this new technology from being used which are mainly: Lack of knowledge and awareness, and in this study we had worked on overcoming that by a good presentation and personal customized awareness talk for each employee about the importance of indoor plants in our lives which we mostly spend indoors. Costbased Barriers, and that was overcome by introducing wall garden some ideas with least costs. also technical issues was indicated as a barrier and that was somehow overcome by continuous looking 
after the units but that was found to be too much work and following up efforts.

\section{Indoor Air Quality is a Shared Responsibility}

Some of the factors that contribute to poor indoor air quality may originate from inadequate HVAC design or solely in the control of the building management, such as maintenance of the HVAC system, others are largely in the control of building tenants and occupants, such as materials used in renovations and products and furnishings brought into or used in the building by occupants.

Finally it can be concluded that the wall garden and indoor plants are beneficial in social, environmental, and economical aspects. Therefore, the installation of the wall garden is recommended ,It is suggested that multi-disciplinary approach as a collaboration among researchers from various fields of architecture, engineering, biology, horticulture, and soil science is highly required to get more realistic and practical results from the studies of wall gardens performance. and through this integrative approach, the development of wall gardens as an indoor method for enhancing better indoor air quality in an urban environment should be expected. Continuous solutions are often lighter than modular systems. But most recent developments of green wall systems design are mostly focused on modular systems, offering advantages of installation, allowing a rapid coverage of the entire surface, and simplifying their maintenance, enabling the disassembly and replacement of each element In the field of green wall characteristics, the main concerns are to find new strategies for a better performance and durability through the integration of water retention materials, drainage means and simpler assembly and maintenance processes as mentioned by Maria Manson,( 2014) . This study proves the importance of increasing the interest in the environmental benefits of the greening system that is exampled in wall gardens. The future research goals should address the investigation of the pollutant removal mechanism, the selection of appropriate plant species and microbial consortia to deal with a variety of organic and inorganic pollutants and should assess efficacy of the technology under a range of conditions.

\section{REFERENCES}

A. Todorova, S. Asakawa, T. Aikoh. (2004). Preferences for and attitudes towards street flowers and trees. Landsc. Urban Planning, 403-416.

Ahmad Hami, Fazilah Fazle Moula, Suhardi Bin Maulan c. (2018, March). Public preferences toward shopping mall interior landscape design in Kuala Lumpur, Malaysia. Urban Forestry \& Urban Greening, Volume 30, Pages 1-7.
Almusaed, A. (2011). Illuminate by light shelves. In Biophilic and Bioclimatic Architecture, 325332.

Blanc, P. \&. (2015). Quai Branly Museum. Retrieved from http://www. verticalgardenpatrickblanc. com/realisations/paris/quai-branly-museum.

Brown, K. \& Jameton. (2000, march 1). Public Health Implications of Urban Agriculture. Journal of Public Health Policy, 21.

Coleman, P. (2006). Shopping Environments: Evolution, Planning and Design. Architectural Press.

epa.

https://www.epa.gov/sites/production/files/ 2014-08/documents/sec_4.pdf.

Fjeld, T. (1995). The Effects of Interior Plants for Offices. Paper presented at the Symposium Plants for people. Amesterdam.

fluke.http://en-us.fluke.com/products/hvac-iaqtools/fluke-975-hvac-iaq.html.

Groenewegen \& Peter P. (2012). Is a green residential environment better for health? If so, why? Annals of the Association of American Geographers, 102.5, 996-1003.

K. Dijkstra a et al. (2011, March ). Stress-reducing effects of indoor plants in the built healthcare environment: The mediating role of perceived attractiveness. Preventive Medicine, 31(1), Pages 99-105.

Kelly Vazquez and Lydia Adams. (2014). The Level of Volatile Organic Compounds Exposure in New Buildings: Can Adding Indoor Potted Plants Reduce Exposure? Proceedings of The National Conference, (p. 532).

Lohr, V.I., C.H. Pearson-Mims, and G.K. Goodwin. (1996). Interior plants may improve worker productivity and reduce stress in a windowless environment. J. of Environmental Horticulture, 14(2):97-100.

Manaker, G. (1996). Interior Plantscapes: Installation, Maintenance, and Management. Prentice Hall.

Mangone, Giancarlo, et al. (2017). Bringing nature to work: Preferences and perceptions of constructed indoor and natural outdoor workspaces. Urban forestry \& urban greening, 23, 1-12.

Maria Manson, J.-G. (2014). Greenwall systems:A review of their characteristics. elsevier, 1-9.

McCalley, James, Eduardo Ibáñez, Yang Gu, Konstantina Gkritza, Dionysios Aliprantis, Lizhi Wang, Arun Somani, and Robert Brown. (2010). National long-term investment planning for energy and transportation systems. In Power and Energy Society General Meeting, 1-7. 
Peck, S., Callaghan, C., Peck and Associates, Bass, B., Kuhn, M., . (1999). Greenbacks from Green Roofs: Forging a New Industry in Canada. Prepared for Canada Mortgage and Housing Corporation, canada ,ottawa.

R. Kaplan, S. Kaplan, R.L. Ryan. (1998). With People in Mind: Design and Management of Everyday Nature. Island Press.

Rajkhowa, Bhargav R. (2016). Establishing and improving control stratregies that sustain plant health in a botanical biofilter. Diss. Purdue University.

Roelofsen, P. (2002). The impact of office environments on employee performance the design of the workplace as a strategy for productivity enhancement. Facilities, 1, 3, pp. 247-264.

Shamsuri, Mohd Mahathir Suhaimi, and A. M. Leman. (2015). Indoor Plants as a Filtration of Indoor Air Pollution: A Review. Journal of Occupational Safety and Health, 12.2 .

Shiah, K., \& Kim, J. (2011). An investigation into the application of vertical garden at the new sub atrium.
Smith, Andrew James, Tucker, Matthew and Pitt, Michael (2011). healthy productive workplaces Towards a case for interior plantscaping. facilities.

solutions,

g.

S. http://www.wolfsense.com/directsense-iaqindoor-air-quality-monitor.html.

V.I. Lohr, C.H. Pearson Mims. (2000). Physical discomfort may be reduced in the presence of interior plants. HortTechnology, 53-58.

Virtudes. A, Manso. M. (2012). Green Walls Benefits in Contemporary City.

Wang, Z. (2011). Dynamic botanical filtration system for indoor air purification.

Wolverton, Bill C., Anne Johnson, and Keith Bounds. (1989). Interior landscape plants for indoor air pollution abatement.

Zhou, J. H. (2011). Purification of formaldehydepolluted air by indoor plants of Araceae, Agavaceae and Liliaceae. J Food Agric Environ, 9.3\&4, 1012-1018.

\title{
الملخص العربي
}

\section{مكافحة الملوثات الغازية باستخدام حدائق الجدار الداخلية}

\author{
رغدة رمضان عبد العزيز '، طارق محمود القيعى'، السيد احمد شلبى'، أشرف محمد شحاته'

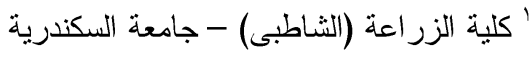

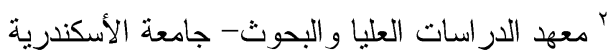

تنتعرض هذه الدر اسة تأثير النباتات الداخلية على التغلب على ملوثات الهو اء الغازية في الأماكن المغلقة مثــلـ

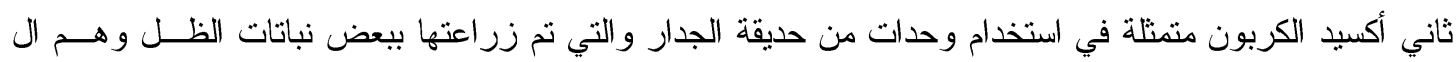

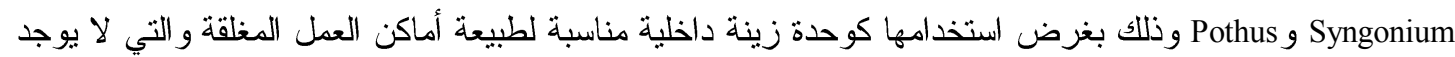

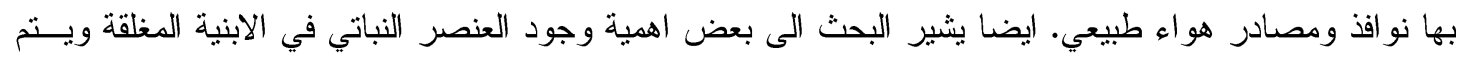

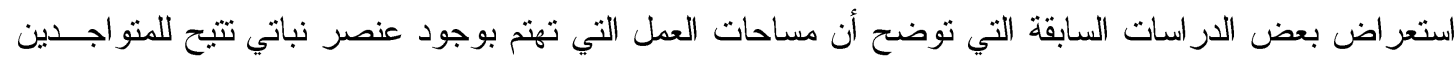

بنلك الاماكن التفاعل مع النباتات مما يغير مو اقف الإنسان وسلوكياته ويحث على تحسن المز اج وزيــادة الإنتاجيــة

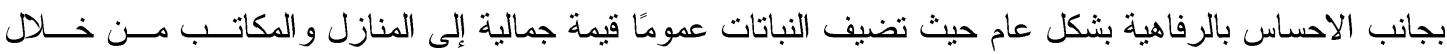

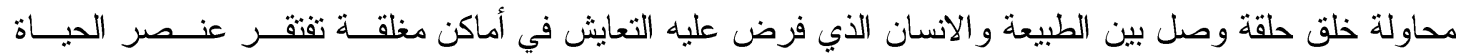

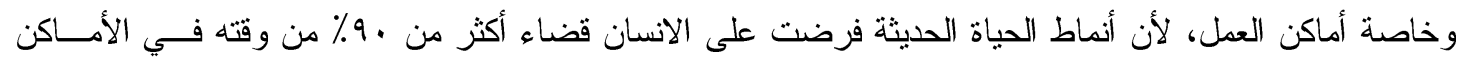

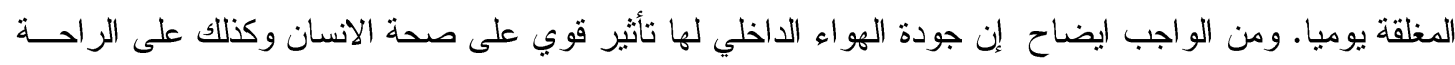

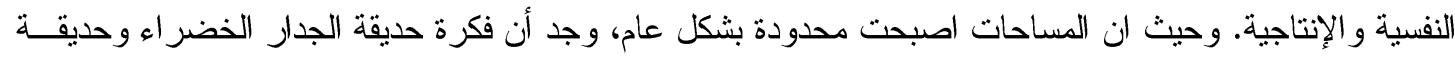

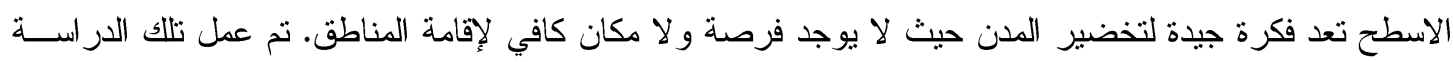


في 1 من المكاتب الخلفية بمكتبة الإسكندرية حيث رعي ان تكون جميع الظروف منماتلة حيث تم تركيب 7 حـدائق

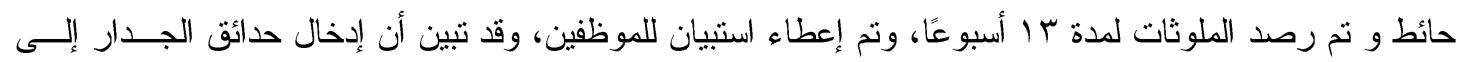

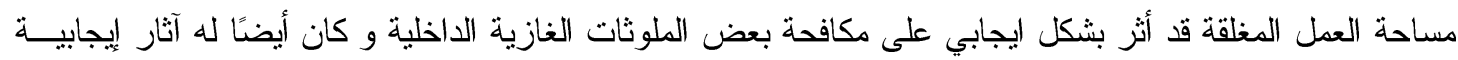

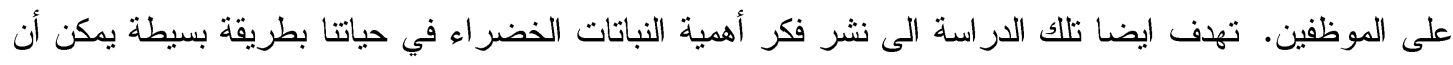

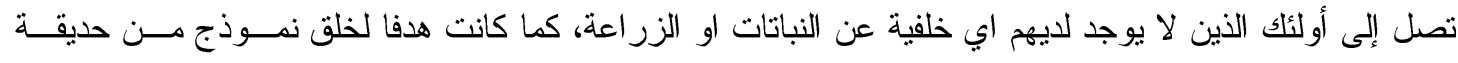

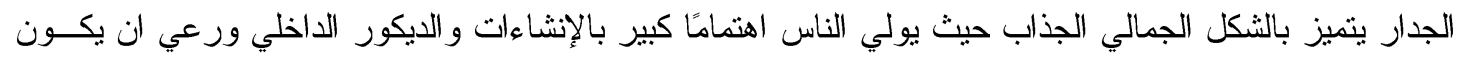

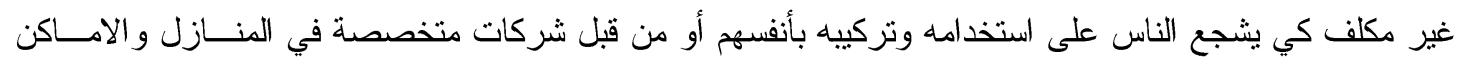

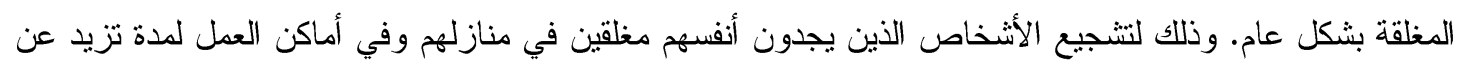

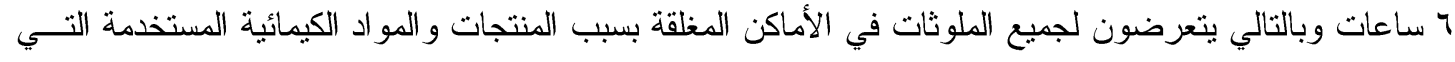

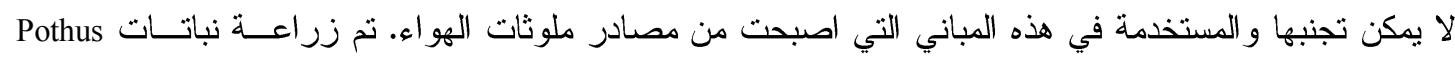

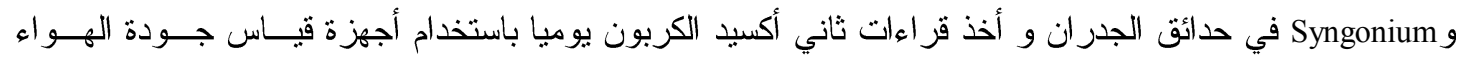

GrayWolf's Highly Advanced Indoor Air Quality (IAQ) Meters - AdvancedSense IAQ Indoor Air Quality Instrument (1) - Fluke 975 AirMeter $^{\mathrm{TM}}$ (2)

كلا الجهازين مملوكان للقطاع الهندسي بمكتبة الإسكندرية و التي ساهمت في ذلك البحث بتوفير اجهزة قيــاس

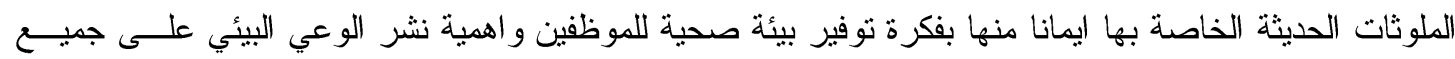
المستويات. 